\title{
A Radical-Mediated Approach to the Total Synthesis of Fluori- nated Marinoquinoline A and Related Tricyclic and Tetracyclic Congeners
}

\author{
Bhaven Patel \\ Stephen T. Hilton* \\ UCL School of Pharmacy, 29-39 Brunswick Square, London, \\ WC1N 1AX, UK \\ s.hilton@ucl.ac.uk
}

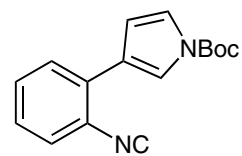

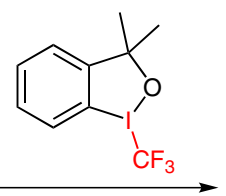<smiles>CCCCn1ccc2c3ccccc3nc(C(F)(F)F)c21</smiles><smiles>FC(F)(F)c1ccc2nc(C(F)(F)F)c3[nH]ccc3c2c1</smiles>

fluorinated marinoquinoline $\mathrm{A}$
Received: 09.06.2014

Accepted after revision: 15.07.2014

Published online: 07.10 .2014

DOI: 10.1055/s-0034-1378614; Art ID: st-2014-d0498-I

Abstract A radical-mediated approach to the core structure of fluorinated marinoquinoline $\mathrm{A}, \mathrm{N}$-methylated marinoquinoline $\mathrm{A}$ and related congeners via the use of Togni's reagent is described.

Key words trifluoromethylation, radical reaction, Togni's reagent, marinoquinoline $A$, tricyclic heterocycles

Despite the diversity and bioactivity of tricyclic heterocycles in the chemical literature, the $3 H$-pyrollo[2,3-c]quinoline ring system remains a rarely reported structural motif amongst natural products. ${ }^{1}$ It was first described in 2007 as the core of the natural product, marinoquinoline A (1a; Figure 1), ${ }^{2}$ isolated from the marine gliding bacterium Rapidithrix thailandica and was shown to be a strong inhibitor of acetylcholinesterase $\left(\mathrm{IC}_{50}=4.9 \mu \mathrm{M}\right){ }^{3}$ Five further derivatives, marinoquinolines B-F (1b-f) were reported in $2011 .{ }^{4}$ These compounds all exhibited moderate cytotoxicity against three cancer cell lines and promising activities against the tropical parasite Plasmodium falciparumK1 $\left(\mathrm{IC}_{50}\right.$ $=1.7-15 \mu \mathrm{M})$. Other examples of natural products containing the $3 \mathrm{H}$-pyrollo[2,3-c]quinoline core include trigonoine $\mathrm{B}(\mathbf{2})$ and aplidiopsamine $\mathrm{A}(\mathbf{3})$ as shown below. ${ }^{5}$

The development of novel methodology to introduce trifluoromethyl groups $\left(\mathrm{CF}_{3}\right)$ into organic compounds has attracted significant attention, due to the fact that it can readily alter the physical, chemical and biological properties of a compound. ${ }^{6,7}$ Fluorinated compounds frequently exhibit improved solubility and lipophilicity, resulting in improved membrane permeability and increased bioavailability in comparison to their non-fluorinated congeners. ${ }^{8}$

From a synthetic standpoint, there are several potential approaches towards construction of the pyrroloquinoline system and accordingly, reported examples include cyclisation of 3-quinolyl hydrazones, ${ }^{9}$ and palladium-catalysed annulations of amine-halogenated quinolones. ${ }^{10}$ Of note, is Correia's description of the synthesis of four members of

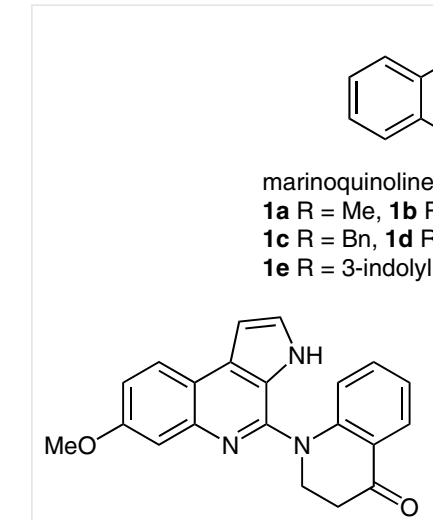

trigonoine B (2)<smiles>[R]c1nc2ccccc2c2cc[nH]c12</smiles>

marinoquinolines $\mathrm{A}-\mathrm{F}(\mathbf{1} \mathbf{a}-\mathbf{f})$

1a $\mathrm{R}=\mathrm{Me}, 1 \mathrm{~b} \mathrm{R}=i-\mathrm{Bu}$

1c $\mathrm{R}=\mathrm{Bn}, 1 \mathrm{~d} \mathrm{R}=4-\mathrm{OHC}_{6} \mathrm{H}_{4} \mathrm{CH}_{2}$

1e $\mathrm{R}=3$-indolyl, $1 \mathrm{f} \mathrm{R}=$ indole-3-carbonyl

Figure 1 Natural products containing the core $3 \mathrm{H}$-pyrollo[2,3-c]quinoline structure

the marinoquinoline family featuring a Heck-Matsuda arylation and Pictet-Spengler cyclisation as key steps. ${ }^{11}$ More recently Banwell reported the total synthesis of marinoquinoline A via a palladium-catalysed Ullmann coupling of nitroarenes with pyrroles. ${ }^{12}$

As a result of the potent biological activities of $3 \mathrm{H}$-pyrollo[2,3-c]quinoline ring systems and our ongoing research into radical additions to isocyanides ${ }^{13}$ (Scheme 1), we now wish to disclose the results of our synthesis of fluorinated derivatives of marinoquinoline A and related structural derivatives.

Aryl isocyanides are well-established radical acceptors in cascade reactions, ${ }^{14}$ as evidenced by reports from Studer who explored the addition of electrophilic $\mathrm{CF}_{3}$ radicals to aryl isocyanides to form 6-trifluoromethyl phenanthridines and 2-trifluoromethylated indoles using Togni's reagent. ${ }^{15}$ We envisaged that under similar reaction conditions, a 6-endo cyclisation would occur from the protected pyrolloisocyanide $\mathbf{9}$ comprising trifluoromethylation and con- 
<smiles>COC(=O)c1ccc([N+](=O)[O-])c(-c2cccn2C(=O)OC(C)(C)C)c1</smiles>

4<smiles>COC(=O)c1ccc2c(c1)C1(C=CCN1C(=O)c1ccccc1)C(SPc1ccccc1)=N2</smiles>

5<smiles>COC(=O)c1ccc2nc(Sc3ccccc3)c3ccn(C(C)(C)C)c3c2c1</smiles>

Scheme 1 Synthesis of either tricyclic or spirocyclic heterocycles

comitant quinoline formation. Subsequent deprotection of the pyrrole ring would result in the 2-trifluoromethyl analogue of marinoquinoline A (7; Scheme 2).<smiles></smiles>

Scheme 2 Disconnection approach to fluorinated marinoquinoline A

Our synthetic approach commenced with the preparation of 3-bromopyrrole-l-carboxylic acid tert-butyl ester (10) as described. ${ }^{16}$ Subsequent Suzuki-Miyaura coupling with 2-iodoaniline (11) gave 12 in good yield. ${ }^{13}$ Formylation<smiles>Nc1ccccc1I</smiles>

10<smiles>CC(C)(C)OC(C)(C)C</smiles><smiles>CC(=O)OC(C)=O</smiles><smiles>CC(C)(C)OC(C)(C)C</smiles>

14

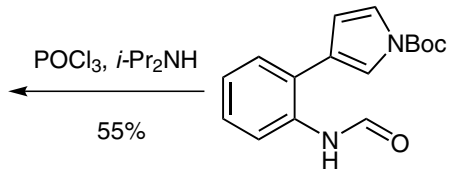

13
Scheme 3 Synthesis of fluorinated marinoquinoline A cyclisation precursor with formic acetic anhydride, ${ }^{17}$ followed by dehydration with phosphorus oxychloride in the presence of diisopropylamine resulted in the required cyclisation precursor 14 in good yield (Scheme 3). ${ }^{18}$

Following the conditions reported by Studer, ${ }^{15 a}$ treatment of isocyanide $\mathbf{1 4}$ with commercially available Togni's reagent $\mathbf{1 5}$ in the presence of tetramethylammonium iodide (TMAI), as the iodide source/initiator, pleasingly gave the 6endo cyclisation product $\mathbf{1 6}$ in $37 \%$ yield and therefore the core $3 H$-pyrollo[2,3-c]quinoline ring system. Unlike in our previous report on the synthesis of spirocyclic and tricyclic heterocycles, we were pleased that under the reaction conditions used, there was no evidence of 5-exo cyclisation, with only 6-endo cyclised product obtained. Subsequent deprotection of the pyrrole protecting group with TFA resulted in trifluoromethylated marinoquinoline A 7 in excellent yield (Scheme 4).

As a result of the success in our synthesis of the core structure of fluorinated marinoquinoline A 7, we elected to carry out further investigations of cyclisations with analogous pyrrole and five-membered heterocycle substituted aryl isocyanides as shown (Figure 2).

Arylamines were synthesised using three approaches. The first reported by Rault, ${ }^{19}$ utilised the Clauson-Kass reaction of nitroanilines with 2,3-dimethoxytetrahydrofuran in acetic acid. Subsequent reduction of 1-(2-nitrophenyl)pyrroles using $\mathrm{BiCl}_{3}-\mathrm{NaBH}_{4}$ resulted in 1-(2-aminophenyl)pyrrole precursor derivatives 17a to 17d in yields of $18 \%$ to $75 \%$ over two steps. Alternatively, use of Suzuki-Miyaura conditions using aryl iodides and commercially available boronic acids, gave the corresponding amine precursors 17e to $\mathbf{1 7} \mathbf{j}$ in good yields. ${ }^{16}$ The third approach involved nucleophilic aromatic substitution of a heteroaryl ring with<smiles>CC1(C)OI(C(F)(F)F)c2ccccc21</smiles>

14<smiles>CC(C)(C)OC(=O)c1ccnc2ccccc12</smiles>

16<smiles>FC(F)(F)c1nc2ccccc2c2cc[nH]c12</smiles>

7

Scheme 4 Synthesis of fluorinated marinoquinoline A 
<smiles>N#Cc1ccccc1-n1cccc1</smiles>

$17 a$<smiles>Cn1ccc(-c2ccccc2[N+](C)(F)F)c1</smiles>

17 e<smiles>N#Cc1cc(C(F)(F)F)ccc1-n1cccc1</smiles><smiles>Cc1ccc(-n2cccc2)c([N+](=O)[O-])c1</smiles>

$17 c$<smiles>CC(=O)c1ccc([N+](=O)[O-])c(-c2ccoc2)c1</smiles>

17g<smiles></smiles><smiles>CC(=O)c1ccc([N+](=O)[O-])c(-c2cc3ccccc3s2)c1</smiles>

17j<smiles>COc1ccc([N+](=O)[O-])c(-n2cccc2)c1</smiles>

17d<smiles>CC(=O)c1ccc([N+](=O)[O-])c(-c2ccsc2)c1</smiles>

17h<smiles>CC(=O)c1ccc([N+](=O)[O-])c(-c2cccn2C(C)(C)C)c1</smiles>

$17 i$<smiles>N#[N+]c1ccccc1-n1ccc2ccccc21</smiles>

17k

Figure 2 Aryl isocyanide precursors in this study

2-fluoronitrobenzene, followed by nitro group reduction with $\mathrm{SnCl}_{2}$ to give precursor $17 \mathbf{k}$ in $25 \%$ yield over two steps. ${ }^{20}$ Formylation with either formic acetic anhydride or ethyl formate, followed by dehydration with phosphorus oxychloride and diisopropylamine proceeded smoothly, resulting in a range of isocyanides $\mathbf{1 7}$. With the corresponding isocyanides 17 in hand, we carried out radical cyclisations using Togni's reagent and TMAI. The resulting 6-endo cyclisations gave a range of tricyclic structures bearing a trifluoromethyl group in the 2-position of the quinoline ring as shown below (Scheme 5).

$$
17 \underset{\text { 1,4-dioxane }}{\stackrel{\substack{\text { Togni's reagent (1.5 equiv) } \\ \text { TMAI (0.05 equiv) }}}{\longrightarrow}} \mathbf{1 8}
$$<smiles>FC(F)(F)c1nc2ccccc2n2cccc12</smiles>

18a, $27 \%$<smiles>Cn1ccc2c3ccccc3nc(C(F)(F)F)c21</smiles>

$18 \mathrm{e}, 39 \%$<smiles>FC(F)(F)c1ccc2c(c1)nc(C(F)(F)F)c1cccn12</smiles>

18b, $25 \%$<smiles>Cc1ccc2c(c1)nc(C(F)(F)F)c1cccn12</smiles>

$18 c,-$<smiles>COc1ccc2nc(C(F)(F)F)c3cccn3c2c1</smiles>

$18 d,-$<smiles></smiles>

$18 f, 31 \%$<smiles>CC(=O)c1ccc2nc(C(F)(F)F)c3occc3c2c1</smiles>

$18 \mathrm{~g},-$<smiles>CC(=O)c1ccc2nc(C(F)(F)F)c3sccc3c2c1</smiles>

$18 \mathrm{~h},-$<smiles>CC(=O)c1ccc2nc(C(F)(F)F)c3ccn(C(C)(C)C)c3c2c1</smiles>

$18 \mathrm{i},-$<smiles>CC(=O)c1ccc2nc(C(F)(F)F)c3c4ccccc4sc3c2c1</smiles>

$18 \mathrm{j}, 53 \%$<smiles>FC(F)(F)c1nc2ccccc2n2c1cc1ccccc12</smiles>

$18 k, 40 \%$

Scheme 5 Cyclisation using Togni's reagent to give a range of tricyclic and tetracyclic derivatives 
The initial precursors (17a-d) were designed to explore the electronic effects of the cyclisation precursor and from the results obtained it was evident that neutral or electrondeficient aryl isocyanides favoured cyclisation. No reaction was observed when electron-rich aryl isocyanides were subjected to the reaction. Following this initial screen, isocyanides $\mathbf{1 7 e}$ and $\mathbf{1 7 f}$ were reacted and successfully underwent 6-endo cyclisation to provide the core $3 H$-pyrollo[2,3-c]quinolone structures $\mathbf{1 8 e}$ and $\mathbf{1 8 f}$. The oxygen and sulfur derivatives $\mathbf{1 7 g}$ and $\mathbf{1 7 h}$ were also investigated, however no reaction was observed and the starting material was recovered. We attributed this to the fact that the lone pairs available to both the thiophene and the furan rings may impede cyclisation of the intermediate radical. No reaction was observed when the $N$-Boc derivative $17 \mathbf{i}$ was subjected to the cyclisation conditions. The lack of reaction can be attributed to the favoured reactivity of pyrroles at the 2-position as reported by Roberts in combination with the fact that the intermediate trifluoromethyl-stabilised $\alpha$-imidoyl radical is electron-poor as opposed to our previous studies, where the $\alpha$-imidoyl radical was stabilised by a thiol. ${ }^{13,21}$ To extend this study, we explored isocyanides $\mathbf{1 7} \mathbf{j}$ and $\mathbf{1 7 k}$ where upon cyclisation tetracyclic structures would be formed. Gratifyingly tetracycles $\mathbf{1 8 j}$ and $\mathbf{1 8 k}$ were obtained in good yields. The extended conjugation in products $\mathbf{1 8 j}$ and $\mathbf{1 8 k}$, combined with the increased nucleophilicity of the benzothiophene and indole rings, may account for the successful cyclisation compared to their pyrrole and thiophene counterparts.

The formation of the trifluoromethylated tricyclic products in preference to their spirocyclic congeners that we ob- served from our previous studies, may be gleaned from the mechanistic work by Studer. ${ }^{15 a}$ Reaction of Togni's reagent 15 with TMAI, results in generation of the $\mathrm{CF}_{3}$ radical and ortho-iodobenzoate $\mathbf{2 0}$ as a by-product. The $\mathrm{CF}_{3}$ radical adds to isocyanide $\mathbf{1 4}$ to generate $\alpha$-imidoyl radical $\mathbf{2 2}$, which can cyclise in a 6-endo or 5-exo manner. However, mechanistically following the work of Studer, the resulting radical is deprotonated by ortho-iodobenzoate to form a radical anion, which further reacts with Togni's reagent via single electron transfer (SET) to furnish the Boc-protected marinoquinoline $A \mathbf{1 6}$ and the chain carrying $\mathrm{CF}_{3}$ radical (Scheme 6). In contrast to our previous studies where the intermediate radical could abstract hydrogen from thiophenol, the intermediate radical 23 resulting from 5-exo addition is unable to be deprotonated by ortho-iodobenzoate and as such the 5-exo product is not observed.

In summary, we have developed a novel approach to 2-trifluoromethyl pyrollo[2,3-c]quinoline ring systems starting from readily prepared isocyanides. ${ }^{22}$ This radical process using Togni's reagent has been used in the synthesis of trifluoromethylated marinoquinoline A 7. The biological activities against cancer cell lines and antimalarial activity are currently under investigation in our laboratories and will be reported in due course.

\section{Acknowledgment}

This work was gratefully supported by the first grant scheme from the EPSRC [EP/J01544X/1]. We thank the EPSRC UK National Mass Spectrometry Facility at the Swansea University for spectroscopic services.

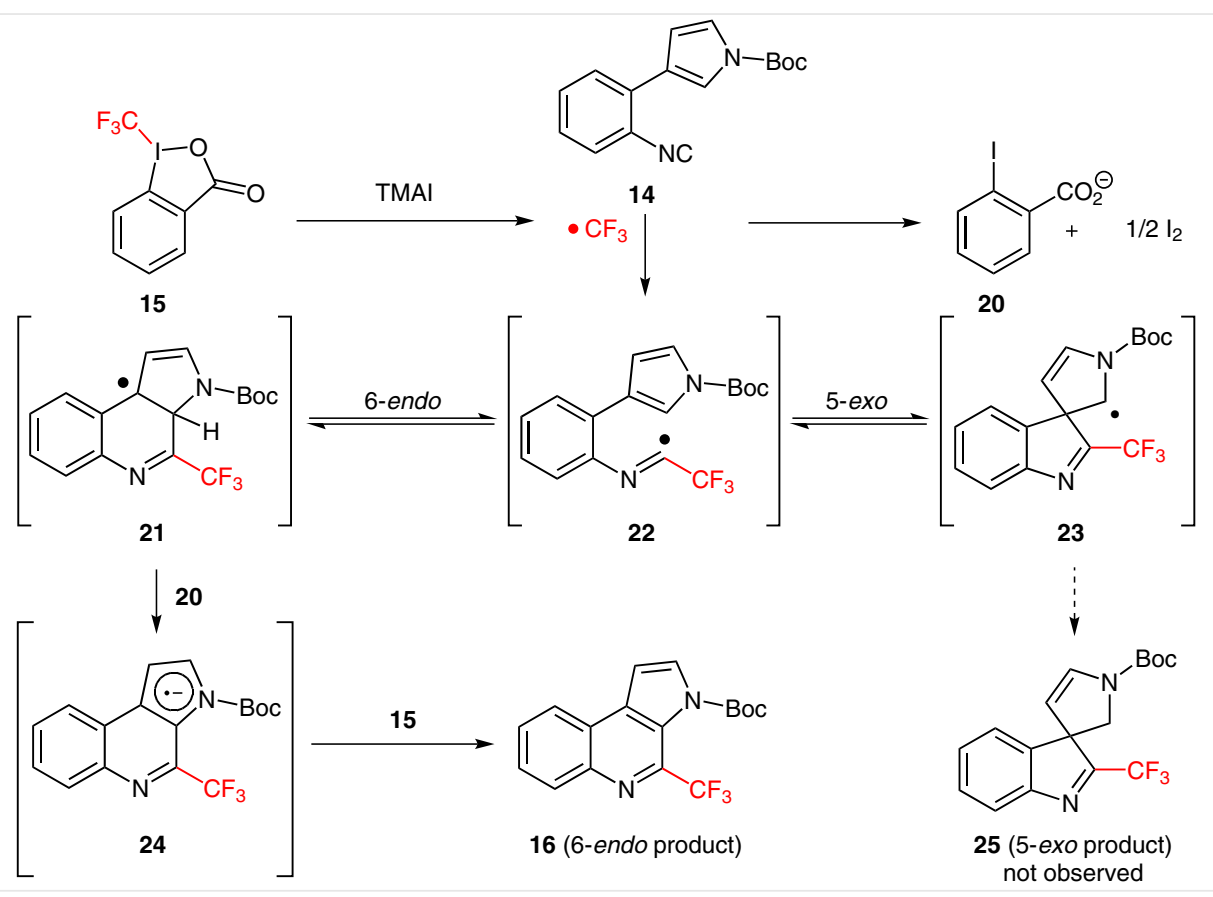

Scheme 6 Synthesis of fluorinated marinoquinoline A 


\section{Supporting Information}

Supporting information for this article is available online at http://dx.doi.org/10.1055/s-0034-1378614.

\section{References and Notes}

(1) (a) Wiesner, J.; Ortmann, R.; Jomaa, H.; Schlitzer, M. Angew. Chem. Int. Ed. 2003, 42, 5274. (b) Almeida, A. I. S.; Silva, A. M. S.; Cavaleiro, J. A. S. Synlett 2011, 2955. (c) Hamada, Y. Chem. Pharm. Bull. 2012, 60, 1. (d) Benakki, H.; Colacino, E.; André, C.; Guenoun, F.; Martinez, J.; Lamaty, F. Tetrahedron 2008, 64, 5949. (e) Testa, M. L.; Lamartina, L.; Mingoia, F. Tetrahedron 2004, 60, 5873.

(2) Srisukchayakul, P.; Suwanachart, C.; Sangnoi, Y.; Kanjana-Opas, A.; Hosoya, S.; Yokota, A.; Arunpairojana, V. Int. J. Syst. Evol. Microbiol. 2007, 57, 2275.

(3) Sangnoi, Y.; Sakulkeo, O.; Yuenyongsawad, S.; Kanjana-Opas, A.; Ingkaninan, K.; Plubrukarn, A.; Suwanborirux, K. Mar. Drugs 2008, 6, 578.

(4) Okanya, P. W.; Mohr, K. I.; Gerth, K.; Jansen, R.; Müller, R. J. Nat. Prod. 2011, 74, 603.

(5) (a) Li, S.-F.; Di, Y.-T.; He, H.-P.; Zhang, Y.; Wang, Y.-H.; Yin, J.-L.; Tan, C.-J.; Li, S.-L.; Hao, X.-J. Tetrahedron Lett. 2011, 52, 3186. (b) Carroll, A. R.; Duffy, S.; Avery, V. M. J. Org. Chem. 2010, 75, 8291.

(6) (a) Müller, K.; Faeh, C.; Diederich, F. Science 2007, 317, 1881. (b) Purser, S.; Moore, P. R.; Swallow, S.; Gouverneur, V. Chem. Soc. Rev. 2008, 37, 320.

(7) (a) Furuya, T.; Kamlet, A. S.; Ritter, T. Nature (London) 2011, 473, 470. (b) Studer, A. Angew. Chem. Int. Ed. 2012, 51, 8950. (c) Ye, Y.; Sanford, M. S. Synlett 2012, 23, 2005. (d) Nie, J.; Guo, H.-C.; Cahard, D.; Ma, J.-A. Chem. Rev. 2011, 111, 455.

(8) (a) Tomashenko, O. A.; Grushin, V. V. Chem. Rev. 2011, 111, 4475. (b) Takeru, F.; Kuttruff, C. A.; Ritter, T. Curr. Opin. Drug Discovery Dev. 2008, 11, 803.
(9) (a) Atkinson, C. M.; Mattocks, A. R. J. Chem. Soc. 1957, 3722. (b) Parrick, J.; Wilcox, R. J. Chem. Soc., Perkin Trans. 1 1976, 2121. (c) Govindachari, T.; Sudarsan, V.; Rajappa, S. Tetrahedron 1961, 16, 1.

(10) Van Baelen, G.; Lemière, G. L. F.; Dommisse, R. A.; Maes, B. U. W. ARKIVOC 2009, (vi), 174.

(11) Schwalm, C. S.; Correia, C. R. D. Tetrahedron Lett. 2012, 53, 4836.

(12) Ma, X.; Vo, Y.; Banwell, M. G.; Willis, A. C. Asian J. Org. Chem. 2012, 1, 160.

(13) Patel, B.; Saviolaki, G.; Ayats, C.; Kapadia, T.; Hilton, S. T. RSC Adv. 2014, 4, 18930.

(14) (a) Curran, D. P.; Liu, H. J. Am. Chem. Soc. 1992, 114, 5863. (b) Curran, D. P.; Ko, S.-B.; Josien, H. Angew. Chem. Int. Ed. 1995, 34, 2683. (c) Nanni, D.; Pareschi, C.; Rizzoli, P.; Sgarabotto, A.; Tundo, A. Tetrahedron 1995, 51, 9045. (d) Yamago, S.; Miyazoe, H.; Goto, R.; Hashidume, M.; Sawazaki, T.; Yoshida, J.-I. J. Am. Chem. Soc. 2001, 123, 3697.

(15) (a) Zhang, B.; Mück-Lichtenfeld, C.; Daniliuc, C. G.; Studer, A. Angew. Chem. Int. Ed. 2013, 52, 10792. (b) Zhang, B.; Studer, A. Org. Lett. 2014, 16, 1216.

(16) Lopez-Tapia, F. J.; Lowrie, L. E.; Nitzan, D. U.S. Patent US 07776910, 2010.

(17) Back, T. G.; Parveez, M.; Wulff, J. E. J. Org. Chem. 2003, 68, 2223.

(18) Obrecht, R.; Herrmann, R.; Ugi, I. Synthesis 1985, 400.

(19) Guillon, J.; Dallemagne, P.; Pfeiffer, B.; Renard, P.; Manechez, D.; Kervran, A.; Rault, S. Eur. J. Med. Chem. 1998, 33, 293.

(20) Fan, L.-L.; Xu, H.; Xu, H. Eur. J. Med. Chem. 2011, 46, 364.

(21) Roberts, J. D. Notes on Molecular Orbital Calculations; W. A. Benjamin Inc: New York, 1961.

(22) General Procedure for Radical Cyclisation: A solution of isocyanide ( 1 equiv), TMAI ( 0.05 equiv) and Togni's reagent (1.5 equiv) in 1,4-dioxane $(0.2 \mathrm{M})$ was heated at $80^{\circ} \mathrm{C}$ for $3 \mathrm{~h}$. The residue was concentrated under reduced pressure and purified via Biotage to give the cyclised products. Full experimental details and characterisation data are available in the Supporting Information.

This article differs from the e-first online version only in its layout; no content has been changed. 